\title{
Tieteen jälkeinen teknologia monoliittisen kulttuurin luojana
}

\begin{abstract}
Raivola, Reijo 1986. Tieteen jälkeinen teknologia monoliittisen kulttuurin luojana. Aikuiskasvatus 6, 4, 183-188. - Koulutuksen yhtenä määrittäjänä on vaikuttajien omaksuma yhteiskuntakuva. Yhteiskunnan sanotaan nyt siirtyneen jälkiteolliseen informaatioyhteiskunnan aikaan, jota kehittyneet tiedonvälitys- ja tuotantotekniikat hallitsevat. Uusi tekniikka on niin läpäisevää, että sen varassa muodostuu uusi teknologisen kulttuurin muoto, joka uhkaa alistaa tieteenkin ohjaukseensa. Tätä jakamatonta kulttuurikäsitystä vastaan on nousemassa kansojen ominaislaadusta ponnistava etnokulttuurinen ja luonnonympäristön rajat tunnustava ekokulttuurinen näkemys, joita kuitenkin on pidettävä eräänlaisina ideologiakriteereinä pikemminkin kuin todellisina vaihtoehtoina esim. kehitysmaille.
\end{abstract}

Tämän paivan keskustelua hallitsee erityisesti viestinnän alalla tapahtuva nopea tekninen kehitys. Kulutushyödykkeiden massiivinen markkinointi iskostaa ihmisiin kuvaa teknisen muutoksen nopeudesta ja samalla voimattomuuden tunnetta teknisen muutoksen edessä. Poliittisten puolueiden ohjelmat heijastuvat teknologisia utopioita yhteiskunnan tulevaisuuden kuvina. Se sama kehitysidea, joka alikehittyneiden maiden modernisoinnissa on kokenut haaksirikon, on omaksuttu teknologiseen suunnittelukieleen puettuna teollistuneiden maiden ja miltei koko maapallomme muutosteoriaksi. Puhutaan historian aalloista ja perustavanlaatuisista yhteiskunnallisista muutoksista ja nimetään suurella paatoksella ovella oleva aika uudella terminologialla. Olemme siirtymässä jälkiteolliseen informaatio- ja tietoyhteiskuntaan. Yhteiskuntien poliittiset valinnat ja elämäntyylit yhdenmukaistavat. Kansallinen kehitys näyttää voimakkaasti olevan sidoksissa kansainväliseen poliittiseen, taloudelliseen, kulttuuriseen ja ennen kaikkea tekniseen kehitykseen. Teknologinen ja deterministinen argumentointi kesyttää kriittisen tutkimuksen uuden kulttuurin osaksi niin, että voidaan oikeutetusti esittää kysymys tieteen itsenäisyydestä. Voimistunut on myös epäilys ennustetun ja väistämättömäksi väitetyn uuden kulttuuriaallon jakamattomuudesta. Monoliittiselle kulttuurikuvalle halutaan löytää vaihtoehtoja.

\section{Teknologian käsitteestä ja tieteen ja teknologian suhteesta}

Teknologia on määritelty monella tavalla. Ahtaasti sillä ymmärretään tuotantoon käytettyjen välineiden ja tekniikoiden summaa. Laajemmin se käsitetään tieteellisten (ennen kaikkea luonnontieteiden ja "'insinööritieteiden") keksintöjen ja saavutusten soveltamisena tarpeittemme tyydyttämiseen. Esim. Unescon määritelmä sisältää lisäksi sovellutusten yhteiskunnallisten, taloudellisten ja kulttuuristen vaikutusten ottamisen huomioon. Laajassa määrittelyssä tieteen ja teknologian käsitteiden merkitysraja hämärtyy. Onhan tieteellinen toimintakin jonkin tarpeen tyydyttämistä ja sen tuloksia arvioitaessa on otettava huomioon samoja seikkoja kuin teknologiaa määriteltäessä. (Toki myös muita). Sosialistiset maat puhuvatkin tieteellis-teknisestä vallankumouksesta, jolla ne tarkoittavat samaa kuin kapitalistiset jälkiteolliseen informaatioyhteiskuntaan siirtymisellä. Filosofisesti ja moraalisesti on oikeutettua puhua tieteenjälkeisestä teknologiasta, niin paradoksaaliselta kuin se edellä esitetyn rinnastuksen valossa tuntuukin. Kysymyksessä on siis joko tieteen sulauttaminen teknologiaan tai sen alistaminen totaalisesti teknologian avustajaksi. Koulutusinstituutio näyttelee tärkeätä roolia tässä tieteen itsenäisyyden menettämisprosessissa. 
"Puhdasta" tiedettä toki vielä kunnioitetaan ja tiedemiehiä arvostetaan, mutta samalla ihmetellään, miksi heidän nauttimansa harrastelu pitäisi kustantaa julkisista varoista. Korkeakoulut ja tutkimuslaitokset saavatkin kaikkialla (suunnitelmatalouden ulkopuolella) enenevässä määrin rahoituksensa eri intressiryhmiltä, kansalaisjärjestöiltä ja - mikä merkittävää - sotilasorganisaatioilta. Mutta vain sellaisia projekteja rahoitetaan, joista on odotettavissa nopeita ja konkreettisia tuloksia. Tuloksilla tarkoitetaan aineellisia tai aineettomia tuotteita, jotka tavalla tai toisella ovat markkinoitavissa, jotka siis tuottavat. Paino asetetaan lyhyen tähtäyksen kustannus/hyöty -tarkastelulle. Yhteiskuntatieteilijät ja humanistit saavat vain ihmetellä, mistä saavat resurssinsa, heillä kun ei ole "näyttöä". Kuvaavaa on esim. meillä esitys "'superprofessoriluokan" muodostamisesta ratkaisuna professorikunnan palkkausongelmaan ja aivovuotoon. Ei tarvitse omistaa suuria ennustajan lahjoja, kun arvioidaan, mistä tieteenaloista nämä nykyajan teräsmiehet poimitaan.

Palataanpa sotilassektoriin rahoittajana. Tuskin OECD-maiden ministerit olivat kotiutuneet syksyllä -85 Pariisin Eureka-kokouksesta, jonka tarkoitus oli muodostaa Yhdysvalloille ja Japanille huipputeknologian alalla eurooppalainen vastavoima, kun jo Pariisista kuului ehdotus, että tulisi pystyttää oma tähtien sota -ohjelma. Huipputeknologian ominaisuuksiin kuuluu, että sen ideologia - johon palaan myöhemmin - on nieltävä karvoineen kaikkineen. On jonkin kansakunnan poliittinen johto tai kansalaismielipide mitä mieltä tahansa esim. kauhun tasapainosta ja sotilaallisesta varustamisesta, aseteknologian kehittelyyn on mentävä mukaan. Se ei tapahdu niinkään poliittisen tai sotilaallisen painostuksen vuoksi kuin siitä syystä, että muuten jää sivuun myös rauhanomaisesti ja kaupallisesti hyödynnettävistä teknisistä innovaatioista.

Toisaalta tieteen ja teknologian konkreettiset tuotokset voidaan omistaa. Niistä tulee kilpailuase muita vastaan ja vallankäytön tärkeä väline. Teknologista kehittelyä hyödyttävästä tutkijasta tulee mustasukkaisesti varjeltava voimavara. Tämä johtaa salaamiseen ja yksityisyyden lisääntymiseen, vaikka teknologia muuten antaakin lähes rajattomat mahdollisuudet yksilön kontrolloimiseen ja hänen yksityisyytensä alituiseen loukkaamiseen. Tieteellisen ja teknologisen tiedon vapaata kulkua joudutaan rajoittamaan. (Niinpä Suomikin epäluotettavana pääsi vasta takaovesta Eurekan piireihin.) Edessä saattaa olla orwellimainen kuva ulko-, puolustus- tai kauppaministeriön sensorivirkamiehestä, joka tarkastaa tieteellisiin kokouksiin matkustavien tiedemiesten esitelmäpaperit. (Kutsch 1985.)

Kanonisoitunut tiede keskittyy kaikella tarmollaan kulttuurin spatiaaliseen ja horisontaaliseen ulottuuvuuteen ts. tämänhetkisen elämänpiirin ymmärtämiseen ja hallintaan. Se kehittää huippuunsa tekniikat, jotka helpottavat ihmisen materiaalista hyvinvointia ja jotka materialisoivat ihmisen henkiset tarpeet. Kulttuurin temporaalinen ja vertikaalinen sisältö syrjäytetään ts. refleksiivisen itsetietoisuuden tuoma ymmärrys kohtalostaan, tehtävästään ja asemastaan luomakunnassa sekä dialektiik$\mathrm{ka}$, joka seuraa siitä, että kuolevaisena on hetken elossa ja toiminnassa, jona historiallisesti mitättömänä aikana hän kuitenkin painaa lähtemättömät jäljet ympäristöönsä. Materiaalinen sitoutuminen jatkuvaan muutokseen, lisääntyvien ja herätettyjen tarpeiden tyydyttämiseen ja muutokseen taloudellisen toiminnan ehtona muodostaa sosiopoliittisen voiman, joka samastaa tieteen evoluution käsitteen kanssa. Silloin tieteeltä perinteisesti vaadittu objektiivisuus ei merkitsekään hellittämätöntä totuuden etsintää ja sitoutumista perimmäisiin arvoihin, kulttuurin kolmanteen koriin (vrt. ETYK-asiakirja) vaan neutraalisuutta. Tutkijasta tulee moraalinen eunukki, joka ei enää ota vastuuta löydöksistään. Hänen ei tarvitse murehtia, mihin tieteen tuloksia käytetään. Evoluution nimissä, teknologiaa kumartaen, hän voi täysin rinnoin ihmiselle lajityypillistä itsekkyyttä osoittaen todistaa epäilijälle, että ns. edistys on luonnon laki. Tiedemiehestä on tullut teknologi, tieteestä tutkimus- ja kehitystoimintaa $(R \& D)$ ja edistys mitataan tehtyinä teknisinä innovaatioina. Kulttuurimme on siirtynyt tieteenjälkeiseen teknologian aikaan, jolloin puhtaasti inhimillisestä uteliaisuudesta ponnistavalta tiedonetsinnältä kielletään oikeutus. Kaikki kulttuuri-instituutiot valjastetaan tieteen ja teknologian sulautumisen edistämiseen (esim. koulutus) tai ne saavat ominaislaatunsa teknologisesta kulttuurista (esim. taide ja vapaa-ajan toiminta).

\section{Teknologinen kulttuuri (LKT)}

Kristinuskon eräät tulkinnat antoivat ihmiselle vapaat kädet yli muun luomakunnan. Päädyttiin peräti antroposentriseen maailmankäsitykseen, jossa luonto käsitettiin ihmisen palvelijaksi, jopa orjaksi. Luonnontieteiden 
nopea kehitys yhdistyneenä Weberin osoittamaan protestanttiseen etiikkaan loivat tuotantomuodon, jolla yhteiskunnan taloudellinen perusrakenne pystytettiin. Muodostuva teollinen teknologia sai monoliittisen sisällön, ja nykyinen informaatioteknologia tai huipputeknologia (high tech) on sen perillinen. Länsimainen kapitalistinen teknologia (LKT) nähdään yleismaailmallisena normina ja kaikki vaihtoehtoiset teknologian muodot tehottomampina, huonompina ja näin hylättävinä. Puhukoon seuraava esimerkki puolestaan.

Vietnamin sodan amerikkalainen helikopterilentäjä (Mason 1984) kuvaa kirjassaan 'Chickenhawk' reaktioita, jotka hänen ihailunsa paikallisesta kylästä löytämäänsä siroa tuolia kohtaan herätti. Tuoli oli valmistettu ilman liimaa, nauloja ja ruuveja. Sen idea oli siinä, että istujan paino kiristi liitokset lujiksi. "'Eivätkö vinosilmät edes liimaa ja puristinta tunne', kuului tavallinen kommentti taideteoksesta.

LKT on nykyaikaisen kulttuuridiffuusion muoto. Se leviää kuin kulkutauti kaikkialle, toisin kuin teollinen vallankumous $1700-$ ja 1800-luvulla. Se koskee yhtä hyvin kehittyneitä kuin kehittymättömiä maita, yhtä hyvin kapitalistisia kuin sosialistisia yhteiskuntamalleja. LKT on luonteeltaan patriarkaalista ja se rakentuu kapitalistiselle työn organisaatiolle ja pääoman filosofialle. Pääoman logiikalle on väistämätöntä luonnon ja ihmisten riistäminen. Siirtomaavallan aikana riistettiin raakaaineita (tietysti näin tehdään vieläkin), huipputeknologian aịkana työvoimaa esim. siirtämällä tuotanto halvan työvoiman maihin. LKT vaatii työntekijöiltään kokonaisvaltaisen sitoutumisen työhön: ajatuksesikaan eivät saa olla vain omiasi, vapaa-aikasi ei kuulu vain sinulle. Teollinen vallankumous merkitsi työntekijän fyysisen riistämisen voimistamista, LKT henkisen. Juuri LKT:n ideologinen sitoutuneisuus kapitalistiseen tuotantomuotoon saattaa olla teollistuneiden sosialistimaiden teknologisten ongelmien ja ristiriitojen perimmäinen syy.

LKT:n ideologiaan kuuluu usko tekniseen kehitykseen ja muutoksen väistämättömyyteen. LKT on ensimmäinen kulttuurimuoto, joka ei pelkää muutosta vaan pyrkii sitä aktiivisesti saamaan aikaan. Se uskoo kasvuna määriteltyyn kehitykseen itseisarvona ja inhimillisyyden lisääjänä. Se katsoo vapauttavansa sosiaaliset suhteet niin työssä kuin muussakin kansalaistoiminnassa.

Uudenaikaiset asenteet ymmärretään sitoutumisena LKT:n ideologiaan, näin myös kehitysmaissa. Uskotaan, että LKT tuottaa "voittoa kaikille" vaikka kuinkakin epäsuorasti.
LKT:n monimutkaisuus ja läpäisyvaatimus edellyttävät koulutusjärjestelmän voimakasta muokkaamista koulutuksen työvoimafunktion korostamiseksi.

Nämä uskomukset ohjaavat teknologista yhteiskuntapolitiikkaa. Päämäärät sorvataan teknisten mahdollisuuksien mukaan, jolloin teknologisista normeista tulee keskeisiä inhimillisiä arvoja. Jyrkästi kielletään, etteikö teknologia olisi käyttäjiensä valvonnassa. Kuitenkin teknologinen rakenne säätelee, mitä pidetään sosiopoliittisena ongelmana. Lisäksi teknologian aiheuttamien ongelmien ratkaisua etsitään puolestaan teknologiasta. Kuvaavaa on teknologian työllisyydelle aiheuttamiin ongelmiin suhtautuminen. Työ tai sen puute ei enää olekaan määrätynlaisen sosiaalisen järjestelmän tuote ja poliittisen päätöksenteon seuraus vaan teknologisten pakotteiden aiheuttama. Poliittis-moraaliset arvot on käännetty teknishallinnollisiksi eli "objektiivisiksi" totuuksiksi. (Vrt. Habermas 1971.)

Teknologia tuo ilman muuta mukanaan poliittisia ja moraalisia ongelmia. Se aiheuttaa arvojärjestelmämme uudelleenorganisoinnin. Teknisestä eksperttiydestä tulee vahva ideologinen voima, koska sillä on merkittäviä sosiaalisia ja poliittisia vaikutuksia. (Bash 1985.) Teknologista kulttuuria läpäisevä ideologia kuitenkin depolitisoidaan tekniseksi determinismiksi. Teknologia ja sen edustajat mystifioidaan ja niiden ympärille rakentuu oma mytologiansa. Mytologiaa testaavat ja poliittiset toisinajattelijat vaimennetaan vetoamalla kansainväliseen kilpailukykyyn, kehityksen mukana pysymiseen ja elintason nostamiseen.

Theo Cerdeira on koonnut LKT:aa kuvaavan mallin, jossa ihminen sidotaan erilaisin relaatioin yhteiskuntaan, ympäristöön, tietoon ja teknologiaan. Lukija voi itse seuraavan mallin avulla muodostaa teknologisia kulttuurihypoteeseja, jotka selittävät yhtä hyvin syitä kuin seurauksiakin siinä kulttuurissa, jossa teknologia ja käsitys tiedosta sitovat ihmisen ympäristöönsä ja kanssaihmisiinsä. (Cerdeira 1985.)

Seuraavassa joitakin johtopäätöksiä mallista:

- LKT:n käsitys hyvästä yhteiskunnasta samastaa elämisen laadun elintason korkeuteen.

- Tieteellisessä toiminnassa ne keksinnöt, jotka optimoivat taloudellisen panos/tuotos -suhteen, saavat etusijan henkisistä, sosiaalisista ja ekologisista kustannuksista huolimatta. 
Kuvio. Malli ihmisen relaatioista

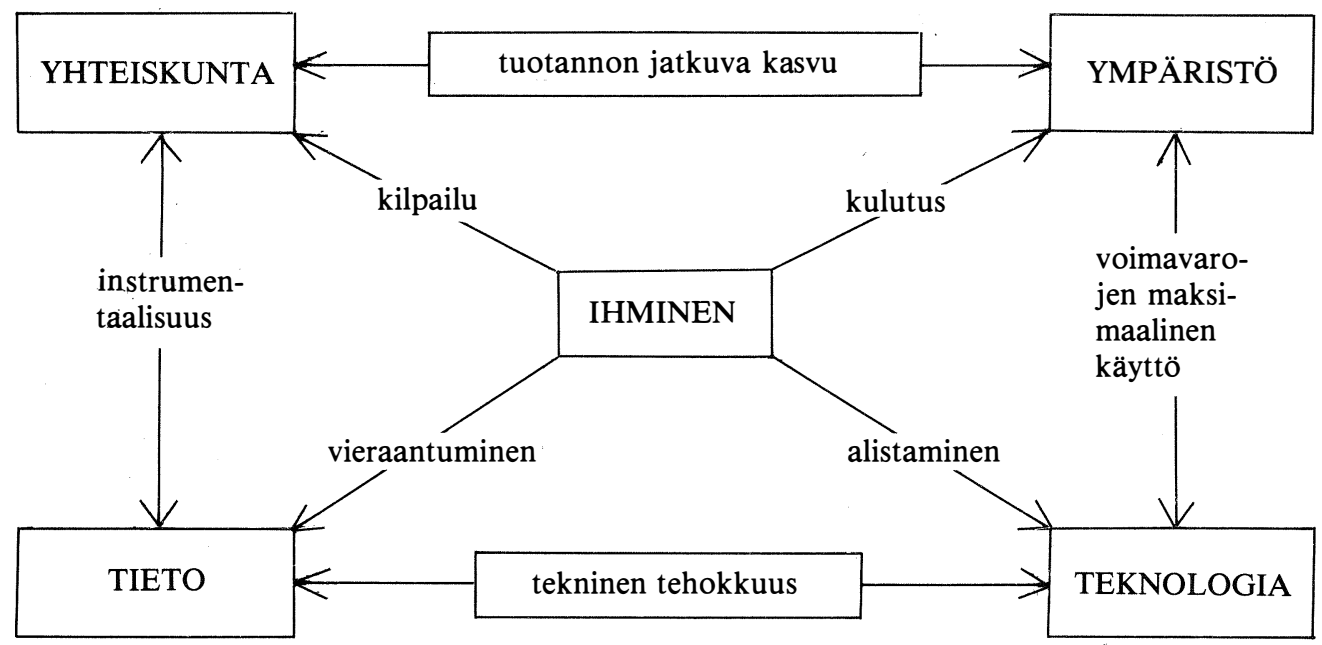

- Ihminen tulee kouluttaa hyödyke- ja palvelufetisismiin, jotta tuotannon ja markkinoiden jatkuva kasvu olisi mahdollista. Onni on omistamista ja palveltavana olemista.

- Ihmisestä tulee entistä selvemmin tuotannon vieraantunut objekti.

- Ihmisestä tulee yhä kapea-alaisemman sirpaletiedon tuottaja ja kuluttaja. Tietorakenteiden muodostaminen käy yhä vaikeammaksi.

- Ihmisen itsekkyys ruokkii sosiaalidarwinismia ja päin vastoin.

Koulutuksen oletetaan luovan yleiset edellytykset mallin läpäisylle. LKT on jo pitkään ollut voimakkain opetussuunitelmien muutosagentti. Koulu yhdessä joukkoviestimien kanssa harjoittaa ajatusten sosiaalista kontrollia ja pitää näin kansalaiset sitoutuneina välineelliseen kasvun ideologiaan, ts. heidän tietoisuutensa kyllästetään LKT:n monoliittisella kulttuurinäkemyksellä. Tässä kohtaa olen kuulevinani voimakkaita vastaväitteitä. Kuuluuhan opetussuunnitelmiin kaikilla koulutusaloilla humanistista ja yhteiskunnallista ainesta, korostetaanhan opetuksessa kriittistä suhtautumista jaettuun informaatioon jne.. Kuitenkin LKT nielaisee koulutuksen - kaikkina aikoina koulutus tukee vallitsevaa ideologiaa. LKT:aa vastaan ei ole valinnan mahdollisuutta. Vai voivatko koulutusjärjestelmät valita eri teknologiakäsitysten välillä, voidaanko teknologia ottaa vain tekniseksi osaksi opetussuunnitelmia sitoutumatta sen ideologiaan tai auttaako opetussuunnitelma nuoria tekemään valintoja eri teknologioiden välillä? Nuori nähdään siemenenä tai munana, jonka kuoreen koulutuksessa voidaan pakata kaikki tuleva. Jos kasvuhäiriöitä tai mutaatioita uhkaa syntyä, korjataan uhka saman ideologian mukaisella täydennys-, jatko-, uudelleen- tms. koulutuksella.

Jos LKT:aa arvioi yleisinhimillisten elämää säilyttävien normien valossa, näkymä on pelottava:

1. Omaksuttu teknologia ei saa luoda uhkaa elämälle, psyykkiselle ja fyysiselle terveydelle tai lajien säilymiselle.

2. Se ei saa uhata fyysisen ympäristömme tasapainoa ja itsesäätelymekanismeja.

3. Se ei saa lisätä sosiaalista epäjärjestystä ja tyytymättömyyttä.

Yhteiskunta- ja koulutuspolitiikalle voidaan näistä puolestaan johtaa vaatimus, että ne eivät saa edistää edellä esitettyjen normien vastaista ajattelua tai toimintaa.

Omaksutussa kulttuurimallissa yhteiskunta hylkää jäsenensä yksilöinä ja itseohjautuvina tiedostavina olentoina. Se ei tarjoa pohjaa eikä aineksia elämän perustaksi. Siksi kaikkialla kuumeisesti etsitään merkitystä minälle, ihmisyydelle ja olemassaololle. Seurauksena on lahkoistuminen: on fundamentalisteja, vihreitä, mystikkoja jne.. Näiden lahkojen ajatusten totuus ei sinällänsä ole tärkeä. Tärkeätä on välimatka, joka onnistutaan luomaan viralliseksi julistettuun totuuteen, mitä pidempi sitä parempi. Yhteiskunnan virallinen totuus, joka on latistunut truismiksi, tarjoaakin lämpimän kasvualustan fanaattisuudelle, jopa anarkialle, mikä puolestaan syventää lahkoutuneiden eristyneisyyttä. LKT:aa tukevan koneiston (mm. 
valtiokoneiston) on silloin helppo vaieta, ymmärtää tai syleillä dissendentit kuoliaaksi. Jos tämä strategia ei pure, aina on mahdollista institutionalisoida esitetty kritiikki. Näin tapahtui $\mathrm{mm}$. hippiliikkeelle kaupallistamalla ja narkotisoimalla se.

\section{Vaihtoehtona etno- ja ekoteknologia}

LKT:n mahtavasta läpäisyvoimasta huolimatta ja sen suhteellisesta nuoruudesta johtuen on vielä olemassa vaihtoehtoja sen tunnelinäkymälle. On myös esiintynyt laajamittaisia tietoisia yrityksiä irtautua siitä, esim. Kiinan kulttuurivallankumous on osittain laskettava sellaiseksi. (Sen epäonnistuttua on kelkka käännetty täydellisesti. Peläten onkin odotettava, millaisia yhteiskunnallisia ja ekologisia mullistuksia aiheutuu miljardikansan johdattamisesta kulutusyhteiskunnaksi.) Vielä selvempi erkanemisyritys on islamilainen vallankumous.

Etnoteknologiseksi voidaan sanoa kulttuuria, joka ottaa huomioon kansakunnan erityispiirteet, sen historian, luonnonvarat, ilmaston ja maantieteen sekä maailmankäsityksen muovaaman subteen luontoon, sen ihmis- ja yhteiskuntakäsityksen, sen normit ja arvot. Teknologiaa ei voi peruuttaa tai keksiä pois, mutta se voidaan alentaa ideologiasta välineeksi. Taloudellisen tehokkuuden asemesta voidaan ensisijaisesti kiinnittää huomio teknologian sosiaalisiin, yhteiskunnallisiin, kulttuurisiin ja kansainvälisiin vaikutuksiin. Etnoteknologisen vaihtoehdon tunnustaminen merkitsee nykyisen eriarvoistavan taloudellisen maailmanjärjestelmän purkamista, joka on ollut tärkeä LKT:n synnyn syy ja sen ylläpitäjä. Etnoteknologia merkitsee paikallisten olojen kunnioittamista. Se merkitsee oikeudenmukaista kansainvälistä työnjakoa ja solidaarisuutta, se merkitsee kansojen taloudellisen itsemääräämisoikeuden tunnustamista. Se merkitsee blokkiutumisesta pidättymistä ja aseteknologian hylkäämistä, joka alistamisen välineenä aina väistämättä on vankin LKT:n tukipilari.

Etnoteknologian on LKT:aa helpompi edustaa ekologista näkemystä. Ekoteknologia pyrkii tasapainotilaan teknologian ja fyysisen sekä sosiaalisen ympäristön välillä. Se pyrkii kulutustasona määritellyn elintason korvaamiseen elämisen tasolla. Edellä esitettyyn Cerdeiran malliin sovellettuna ekoteknologiset perusre- laatiot muodostuvat seuraaviksi:

- yhteiskunta/ympäristö: taloudellinen tasapaino

- ympäristö/teknologia: ekologinen tasapaino

- teknologia/tieto: sosiaalinen vaikuttavuus

- tieto/yhteiskunta: humanismi

- ihminen $\longrightarrow$ yhteiskunta: yhteistyö ja vapaus

- ihminen $\rightarrow$ ympäristö: säästäväinen käyttö

- ihminen $\rightarrow$ teknologia: hallinta

- ihminen $\rightarrow$ tieto: älyllinen ja moraalinen valppaus.

Koulu voi opettaa teknologian vastuullista käyttöä ja sen sosiaalisia ja taloudellisia vaikutuksia. Se voi osoittaa yhteyden omaksutun teknologian ja tuotantosuhteiden välillä. Se voi kytkeä teknologian kansalliseen ja kansainväliseen kerrostuneisuuteen, kulttuuritraditioihin ja poliittisiin järjestelmiin. Koulutusjärjestelmän on tarjottava rakenteissaan ja sisällöissään vaihtoehtoja. Ilman mielikuvitusta ja henkeä toimiva koulu, valtaideologiaa kaikuna toistaen, muodostuu indoktrinoivaksi laitokseksi, joka harjaannuttaa ihmiset valtioja taloussysteemin osiksi, ilman että he pystyvät ymmärtämään, vastustamaan tai muuttamaan sitä (vrt. Chaplinin Nykyaika). Koulutuksessa on teknisen tietämyksen antamisen ohella purettava teknologian myytit ja paljastettava sen perustana olevat arvot, uskomukset ja valtarakennelmat. (Coulby \& Jones 1985). Näistä tehtävistä selviäminen ei luonnollisesti ole helppoa, koska kulttuurievoluution suunnan kääntämiseen liittyy uskonnollisia, ideologisia ja nationalistisia kaikuja sekä eettistä ja moraalista sitoutumista. Yhteiskunnan ja sen kulttuurin muutos merkitsee ihmisen ja yhteiskunnan ideaalikuvan muutosta. Koulutusinstituution syvällinen muutos edellyttää aina uutta ideologista sitoutumista kaikilla päätöksenteon tasoilla. Koulutusmuutosta ei milloinkaan voida saada aikaan irrallisena innovaationa.

\section{Johtopäätös}

Eko- ja etnoteknologiaan liittyy kuitenkin paradoksi. Jos teknologista kulttuuria ajatellaan systeeminä (kuten esim. Cerdeiran malli tekee), yhden osan muuttaminen vaikuttaa sen relaatioihin muuttavasti ja nämä puolestaan muiden osien suhteiden muuttumiseen. Ei siis voida ottaa ekomallista yhtä osaa korvaamaan LKT:n jotakin osaa tai päin vastoin. Ekomalli- 
kin on otettava kokonaisuutena. Taistellessaan LKT:n ideologiaa vastaan se antaa ainoaksi vaihtoehdoksi oman ideologiansa. Näinhän aina käy! Arvoilla ei kuitenkaan ole totuuskriteeriä. Tämänhetkisessä maailmantilanteessa näyttää siltä, että ei ole olemassa edes globaalisia "perimmäisiä arvoja". Ideologian omaksumiskriteerit muodostuvatkin vallasta, voimasta ja - demokratiassa - enemmistöstä, juuri tässä järjestyksessä. Valinta teknologioiden välillä ei ole empiiris-rationaalinen vaan emotionaalis-moraalinen valinta, ja vahvimman emootio, moraali ja argumentaatio ovat aina oikeassa.

Paradoksi johtuu siitä, että ne vaihtoehtoiset teknologiset mallit, joita edellä on luonnehdittu, ovat yleensä LKT:n sisällä syntyneitä ideologiakritiikkejä. Niiden edellyttämiä käytännön ratkaisuja ei olekaan tarkoitettu vakavasti otettaviksi tai niitä tarjotaan kehitysmaiden malliksi. Tarkoitus on pitää yllä teollistuneiden maiden teknistä hegemoniaa. On täysin selvää, että nykyistä ihmismäärää, joka lisäksi on levinnyt kaikkialle maapalloa, ei voida elättää ilman huipputeknologian apua. Nurinkuriselta tuntuisi olla käyttämättä lääketieteen saavutuksia ihmiskunnan hyväksi. Tekniikalla on elämisen laatua parantavat hyvät puolensa.
Teknologiakeskustelussa onkin suurelta osin kysymys tekniikan siunausten oikeudenmukaisesta jaosta, kansainvälisestä tasa-arvoisuudesta. Tähän asti LKT:aa on käytetty usein järjettömästi painottaen ihmiskunnan enemmistön arvojen ja etujen vastaisesti, osaryhmien ja kansojen välitöntä taloudellista etua ajamaan - mikä juuri on johtanut teknologian puhtaaseen kapitalistiseen soveltamiseen.

\section{Lähteet}

Bash L. 1985. Technological change and political awareness in advanced industrial societes. 12th CESE Congress in Antwerp.

Cerdeira T. 1985. Education and societal reconstruction within the context of contemporary technological development. 12th CESE Congress in Antwerp.

Coulby D. \& Jones C. 1985 . Technologies and curriculum choice. 12th CESE Congress in Antwerp.

Habermas J. 1971. Toward a rational society: London: Heinemann.

Kutsch G. 1985. The impact of post-scientific society. 12th CESE Congress in Antwerp.

Mason R. 1984. Chickenhawk. London: Sage. 